\title{
Kolegium ř́mského práva v Pavii a letní škola v Neapoli aneb jak se o starověkém Římě dozvědět víc
}

Kdo se zajímá o starověké právní řády, především o právo antického Říma, má několik možností, jak prohloubit své znalosti. Vedle těch, které nabízí studijní programy na právnických fakultách, lze navštěvovat také různé konference a setkání právních historiků (a mezi nimi romanistů) pořádané jak českými či slovenskými univerzitami, tak v evropském, př́padně celosvětovém měřítku.

Ve vztahu k výše uvedenému zmiňme alespoň česko-slovenskou konferenci právních romanistů, pořádanou každý rok na půdě některé z českých či slovenských univerzit, dále nyní již tradiční každoroční právněhistorické setkání doktorandů a postdoktorandů, Letní školu dějin a Dny práva na Právnické fakultě Masarykovy Univerzity, př́padně Trnavské právnické dny, přičemž poslední dvě jmenované akce mají samostatnou právněhistorickou, resp. římskoprávní sekci. Akcí s dopadem do historicko-právní, potažmo v určitém úseku prŕmo romanistické oblasti bychom však nalezli v našem česko-slovenském prostoru samozřejmě více a výše uvedený výčet je nutno brát jako pouhý př́íklad. I v rozšířeném evropském perimetru můžeme začít výčtem různých konferencí, na nichž se setkávají odborníci nejen z evropských zemí, ale mnohdy z celého světa. Jako nejvýznamnější a také největší akci tohoto druhu lze jistě uvést kongres SIHDA (Société Internationale pour l'Histoire des Droits de l'Antiquité), jejíž 72. ročník se v roce 2018 konal na Uniwersytet Jagielloński v Krakově (o tom samostatná zpráva), a který je melting potem pro romanisty ze všech koutů zeměkoule, od Chile po Japonsko. Pro Právnickou fakultu Univerzity Karlovy, jakožto jednu ze zakladatelek, je důležitá konference „Diritto romano e attualità“, kterou bude hostit v roce 2019. Dlužno doplnit že v roce 2018 se o její pořádání postarala Università degli Studi „Magna Graecia“ v Catanzaru na jihu Itálie. U našich západních sousedů se dále například koná Rechtshistorikertag, jehož 42. ročník se uskutečnil v záŕí 2018 v Trevíru.

Všechny výše uvedené akce samozřejmě ve značné míře přispívají k nabývání a formování znalostí a vědomostí o římském právu a účast na nich je př́nosem pro studenty magisterských a zejména doktorských studijních programů zaměřených na právní historii, a romanistiku obzvláště, především proto, že umožňují osvojit si prezentační dovednosti, nebot' na valnou většinu z nich se lze s vlastním př́íspěvkem také přihlásit.

$\mathrm{Z}$ hlediska přístupu $\mathrm{k}$ vědecké práci však daleko více zapůsobí na rozvíjení právního myšlení a poznávání různých metodologických přístupů intenzivnější zapojení v užším okruhu osob. Konfrontace s akademiky z jiných (zejména) evropských států, jiným stylem výuky, či přístupem $\mathrm{k}$ pramenům a samotné vědecké činnosti vede vždy $\mathrm{k}$ obohacení 
a osobnímu rozvoji. Způsob, jakým se v různých zemích přistupuje ke zkoumání problematiky římského práva, se totiž může značně lišit.

Nepřekvapí, že mekkou různých studijních aktivit prohlubujících znalosti o Římu a jeho právním řádu je země s ním bytostně spjatá - Itálie. Níže si dovolím představit dvě akce, jichž jsem se účastnila v roce 2016 a 2017, o nichž lze bez nadsázky říct, že nabijí motivací k dalšímu studiu římského práva a dodají nový úhel pohledu, at' už se v římském právu zaměřujete na cokoli.

\section{Collegio di Diritto Romano - CEDANT}

První z akcí je tzv. kolegium římského práva (Collegio di Diritto Romano). Toto setkání se koná každoročně od roku 2003 (od roku 2012 pak ve dvouletých intervalech) a organizuje jej Centrum studií a výzkumu starověkých práv (Il Centro di Studi e Ricerche sui Diritti Antichi, dále jen CEDANT) na Università di Pavia. CEDANT bylo založeno v roce 2002, od roku 2015 se stalo výzkumným centrem v rámci Právnické fakulty Pavijské univerzity ve spolupráci s Almo Collegio Borromeo.

Kolegium římského práva cílí na prohloubení znalosti účastníků a podporu výzkumu v oblasti římského práva a dalších právních řádů starověku. Každý ročník této akce má předem zvolené téma. Účastníci-posluchači z řad mladých vědců jsou vybíráni CEDANT podle informací přikládaných $\mathrm{k}$ přihlášce - profesního CV a seznamu publikací. V podstatě povinnou součástí je jazyková vybavenost, tedy minimálně co se týče italštiny a angličtiny, které jsou jednacími jazyky, ovšem vzhledem k tomu, že doporučená literatura bývá často i v němčině a francouzštině (ojediněle se vyskytne španělština), cení se i alespoň jejich pasivní znalost. Při výběru posluchačů (ale i přednášejících odborníků) je brán zřetel také na zastoupení různých zemí a tedy metodologický pluralismus. Vybraní uchazeči přibližně dva měsíce dopředu obdrží seznam přednášek a také literaturu sestavenou přednášejícími, kterou je záhodno si předem prostudovat.

Samotné setkání pak probíhá ve formě třítýdenního intenzivního kurzu v měsíci lednu a seznamuje frekventanty s konkrétním tématem v širších souvislostech. Sestává ze série přednášek vybraných odborníků na př́slušnou problematiku, k nimž vždy následuje diskuse, resp. možnost dotazů. Sami studenti (v tomto kontextu ve smyslu studujících v rámci Kolegia římského práva, nebot' mnozí z účastníků jsou již postdoktorandi, kteří na svých univerzitách římské právo vyučují) se mohou do výzkumu zapojit tím, že si naformulují vlastní téma související s analyzovanou problematikou a v září téhož roku pak svůj př́íspěvek v rámci opětovného setkání Kolegia rrímského práva odprezentují, a je-li kvalitní, stane se kapitolou v kolektivní monografii, která je po každém ročníku vydávána a obsahuje jednak písemnou formou vyjádřené přednášky odborníků, ale právě také vybrané kvalitní práce studentů.

Prvním tématem CEDANT byl v roce 2003 Zákon XII desek. V následujících letech následovaly další zajímavé otázky starověkých práv týkající se namátkou městských statutů, přirozeného práva, byzantského práva, předřímských starověkých právních řádů, právní subjektivity, justiniánských Digest, císaře Diokleciána nebo naposledy v roce 2018 Theodosiova kodexu, ale i mnoha dalších.

V roce 2016 téma znělo: The Institutes of Gaius: Adventures of a Bestseller. Transmission, Use and Transformation of the Text (Gaiovy Instituce: dobrodružství jednoho bestselleru. Přejímání, použití a proměna textu). Celkem nás bylo do Kolegia rrímského 
práva vybráno patnáct posluchačů, a to různého zaměření (nejen právní romanisté, ale také klasičtí filologové či historici), i různých národností (z České republiky, Chorvatska, Itálie, Mexika, Německa, Ruska, Švýcarska, Velké Británie). Na programu bylo celkem 21 přednášek, rozdělených do jednotlivých tematických bloků, které účastníkům umožnily prozkoumat Gaiovo dílo takřka od hlavy až k patě, a zároveň zjistit, kolik toho ke zkoumání ještě zbývá (dodejme, že stále mnoho).

První týden (11.-15. ledna 2016) se týkal zasazení Gaiových Institucí do kontextu doby a prostředí, v nichž vznikly. Sérii přednášek zahájil Detlef Liebs (Universität Freiburg) s Biographical Matters (názvy přednášek uvádím všechny v angličtině, ačkoliv značná část byla pronesena $v$ italštině), v níž se řešilo, kdo vlastně byl a odkud pocházel právník Gaius, co víme o jeho životě a co o něm lze zjistit z dobových pramenů. Následovalo zařazení Institucí v rámci ostatních Gaiových děl (The Institutiones in the Context of Gaius' Works), které ve svém příspěvku provedla Ulrike Babusiaux (Universität Zürich). Následující dva přednášející prripravili exkurz do struktury Gaiova díla, jíž porovnávali jednak s dalšími řecko-latinskými díly typu manuálů a také s právními texty, pro ně typickými schématy, členěním a systematikou (Expository Structures in Gaius, in Relation to the Greco-Latin Manuals Tradition, Elisa Romano z Università di Pavia; Expository Structures in Gaius, in Relation to the Juristic Tradition, Federico Battaglia z Universität Zürich). Řeckým vlivem v Gaiově díle z jazykového hlediska (Graecisms in Gaius) se zabýval Bruno Rochette (Université de Liège). Porovnání dvou děl - Gaiových Institucí a Liber singularis regularum (Tituli ex corpore Ulpiani) - z různých hledisek (napr. obsahového, stylistického) se v př́spěvku Gaius and Ulpianus in the Tituli věnoval David Johnston (University of Edinburgh). Posledním přednášejícím prvního týdne byl Johannes Platschek (Universität Wien) s prŕíspěvkem o vztahu Institucí a dalšího Gaiova díla - Res cottidianae (The Res Cottidianae in Relation to the Institutions).

Ve druhém týdnu (18.-22. ledna 2016) nás další odborníci postupně seznámili jednak s historií nálezu textu Gaiových Institucí v 19. století, a dále s přejímáním tohoto textu do dalších kompilací v pozdním starověku. Nejprve však Michel Humbert (Université Paris II Panthéon-Assas) ještě pohovořil o Gaiovi a Zákonu XII desek (The Commentary on the XII Tables and the XII Tables in the Institutiones). Dále se posluchači dozvěděli bližší informace o nalezených papyrech, na nichž se dochovala část textu Institucí (P.Oxy.XVII 2103, Oxyrhynchus, 1927, PSI XI 1182, Antinoe, 1933) v př́íspěvku nazvaném The Institutiones in the Papyri, jejichž obsah mimo jiné i z jazykového hlediska rozebral Marco Fressura (Redhis, Università di Pavia). Následně naši pozornost obrátila na Codex Veronensis, tedy manuskript Gaiových Institucí, který byl objeven v roce 1816, Serena Ammirati (Redhis, Università di Pavia), a to z hlediska pomocných věd historických: paleografie a kodikologie (The Codex Veronensis: Paleography and Codicology). Blíže jsme se tedy zaměřili např́íklad na vzhled manuskriptu, posloupnost listů manuskriptu, použité písmo, materiál, na němž je text napsán, či typ inkoustu. Velice zapáleně pohovořil a téměř jako detektivku či román podal Filippo Briguglio (Università di Bologna) př́běh objevení Veronského manuskriptu v Biblioteca Capitolare ve Veroně (The Discovery and the Edition of the Codex Veronensis: Ancient and Modern Aids for (Re)Reading the Palimpsest). Jedním z hrdinů tohoto příběhu je Scipione Maffei, který v první polovině 18. století ve veronské kapitulní knihovně hledal a také našel vzácné a ztracené manuskripty, mimo jiné také malou část Gaiových Institucí. Že se jedná o toto 
dílo, však tehdy nevěděl. Proto zůstaly Instituce skryty ještě další století, v němž ale postupně sílily náznaky, že knihovna ve svém lůnu skrývá velmi významný právní text. Oficiálním objevitelem se stal až Barthold Georg Niebuhr v již zmíněném roce 1816. K tomu nutno podotknout, že ne náhodou taky bylo vybráno téma Gaiových Institucí pro Kolegium římského práva zrovna v roce dvoustého výročí od jejich nalezení. Po shrnutí dramatické historie objevování Institucí se přednášející zaměřil na původní a moderní techniky čtení a zkoumání tohoto textu vzhledem ke skutečnosti, že se jedná o palimpsest. Z dřívějších metod lze zmínit používání různých agresivních chemických přípravků, které sice vědcům umožnily text přečíst, ale zároveň jej nenávratně poškodily. Moderní bádání využívá např́iklad infračerveného světla, UV záření a fluorescenčního světla, 3D technologie, atd.

Další blok přednášek nás vrátil do období pozdní antiky, a to zvláště ke třem dílům (ale nejen k nim), u nichž bylo analyzováno, do jaké míry přejímají, kopírují či pozměňují text Gaiových Institucí: Epitome Gai (dochovaný jako součást Lex Romana Visigothorum), Institutiones di Augustodunum a Legum Mosaicarum et Romanarum Collatio. Opět jsme se věnovali především rozboru shod a odlišností v porovnávaných textech a na jejich základě určení jejich vzájemného vztahu, ale také datace, původu a účelu těchto textů. Přednášku The Epitome Gai vedl Dario Mantovani (Università di Pavia), který, nutno dodat, je zároveň hlavním organizátorem Kolegií římského práva. Druhý pramen římského práva - Fragmenta Augustodunensia (FA) - přiblížil José-Domingo Rodríguez Martín (Universidad Complutense de Madrid) v př́spěvku The Commentary of Augustodunum on the Institutiones. Zaměřil se na nález tohoto díla, jeho popis z hlediska vizuálního i obsahového a perspektivy jeho dalšího zkoumání. V druhé části příspěvku se pak zabýval významem Augustodunenských fragmentů pro rekonstrukci textu Gaiových Institucí, konkrétně pasáží FA 4, 81-87, týkající se institutu noxálního ručení a v jeho rámci předání mrtvoly, které odpovídají mezeře v textu Gaiových Institucí v 4, 80-81. Na závěr druhého týdne vystoupil Ulrich Manthe (Universität Passau) s tématem Gaius in the Collatio and Other Literary Echoes in Late Antiquity. Instituce tak došly k porovnání s díly autorů západní (např. Boëthius, Isidor ze Sevilly; či s Lex Romana Burgundiorum) i východní provenience (Priscianus, Pseudo-Philoxenus a Pseudo-Cyrillus), větší část přednášky se však zmiňovala především o jejich vztahu s Collatio.

Třetí týden (25.-29. ledna 2016) pokračoval ve zkoumání přenosu textu Institucí do dalších děl pozdní antiky. Dostalo se však i na zhodnocení významu objevu Gaiova díla. Posluchači tedy vyslechli přednášku Rewriting and Interpreting Gaius in Late Antiquity: Linguictic Aspects od Rolanda Ferri (Università di Pisa), který se zabýval charakteristickými znaky pozdně antických výukových, gramatických i právních textů, jako jsou použivání otázek, odpovědí, výhrad a námitek sloužící k oživení zájmu (v rámci výuky), komentářů, opakování, odkazů, i hovorových výrazů (jakoby určených pro veřejnost) či zkratkovitého vyjadřování. Neméně zajímavá byla přednáška Giovanniho Lucchetti (Università di Bologna) Gaius and the Institutiones of Justinian, komparace Institucí, které od sebe dělí téměř čtyři století, které se v rámci zkoumaného tématu nebylo možno vyhnout, vzhledem k tomu, že učební text ze 6 . století je ve velké míře ovlivněn právě Gaiovým dílem. Přednášející opět připomněl, jak významným zdrojem poznání Gaiovy Instituce jsou, nebot' mimo jiné slouží z komparativního hlediska také jako prostř̌edek k ukázání inovací v císařské legislativě, zejména té justiniánské. Poukázal také na to, že v Gaiovi často sporné právní 
otázky nebývají rozřešeny, zatímco v justiniánských Institucích takového případy již nenastávají a jejich rožrešení bývá vysvětlováno pomocí uvedení vývoje daného institutu. Bernard Stolte (University of Groningen), jakožto expert na byzantské právo, se zabýval tím, jak Teofilovy Parafráze odráží text Gaiův a jakými cestami se vůbec text Gaiových Institucí do Teofilova díla dostal (Gaius in the Paraphrase of Theophilus). Další přednáška se týkala šíření antických děl na západě i východě rúmské říše v období od 2. do 5 . stol. n. 1. (The Institutiones: the Readership of the Manuals from the 2nd to the 5th Centuries $A D)$ a Ulrich Eigler (Universität Zürich) se v ní věnoval problematice frekvence kopírování děl a jejich dostupnosti pro čtenáře. To záviselo na několika faktorech, především: a) ekonomické situaci př́slušné osoby, zda si kvůli nákladnosti takovýchto opisů, zejména materiálu, mohla dotčené dílo dovolit - v návaznosti na tento problém pak také vznikaly palimpsesty, přičemž spodní vrstvy textu uchovávají př́imo poklady; a také b) na jejich obsahu, nebot' některá díla byla žádaná a rozšiřovaná více než jiná, případně se ke čtenáři dostala $\mathrm{v}$ podobě citace $\mathrm{v}$ jiných dílech. Diskuse se následně rozpoutala nad označením Gaiových Institucí jako „,bestselleru“, jejíž vyústění znělo: přihlédneme-li k tomu, že jde o specializovanou literaturu určenou pro užší okruh osob, dostaneme odpověd’ - nelze je tak označit v porovnání s běžnými díly ,antické knihovny“, v kontextu právnické literatury je však situace odlišná.

Poslední blok přednášek zahájil Jean-Louis Ferrary (École Pratique des Hautes Études, Paris), který pátral po tom, co a z jakých zdrojů lze zjistit o Gaiovi a jeho Institucích v období před objevem Veronského kodexu (Gaius Before the Discovery of the Codex Veronensis). V porovnání s výsledky pátrání ještě o to více vystoupí do popředí význam tohoto objevu, nebot' díky němu získala romanistika množství nových informací a mohutný impuls k podnícení zájmu o rrímské právo. Výjimečnost Gaiových Institucí také spočívá v tom, že se jedná o jediný text z období klasického práva, který se dochoval v takovém rozsahu. Přednášející zmapoval bibliografii $\mathrm{k}$ Institucím od 15. století, ale věnoval se i zmínkám o něm v dochovaných římskoprávních textech. Cristina Vano (Università di Napoli Federico II) přednášela na téma Gaius and the Rediscovery of History of Law. Zaměřila se především na roli právních romanistů a dalších akademiků při a po objevu Codex Veronensis, přičemž hlavní postavou jejího vyprávění byl samozřejmě C. F. von Savigny, ale také další osobnosti spolupracující na odhalování textu manuskriptu. Poslední přednáška Gaius and the Rise and Fall of Interpolations od Martina Avenaria (Universität zu Köln) o vlivu objevu kodexu Veronensis na výzkum interpolací, zakončila celé jednání Kolegia římského práva.

Během těchto tř́ týdnů se nám Gaius a jeho Instituce představily komplexně, z hlediska různých vědních oborů, a každý z nás získal mnoho nových poznatků, které lze využít v další vědecké práci. Jde o dílo nesmírně zajímavé, a ačkoli je jeho text znám téměř celý již dvě století, a dokonce jej máme i v českém překladu, nedá se říci, že by nenabízel mnoho otázek k zamyšlení a zkoumání.

To, co považuji za jednu z nejdůležitějších složek celého kurzu je propojení práva s dalšími vědeckými obory: historií, ale hlavně klasickou filologií, papyrologií a pomocnými vědami historickými. Při zkoumání pramenů je nesmírně důležité věnovat se jim nejen z čistě dogmatického hlediska, ale zasadit je do kontextu doby, v níž vznikaly. Dalším pozitivem je samozřejmě samotná možnost setkání a navázání kontaktů s vědci z různých 
zemí, a to jak studentů, tak i přednášejících, kteří se většinou pár dní zdrželi, jednání se zúčastnili a do diskuse vnášeli své poznatky a názory.

\section{Letní škola - Università degli Studi di Napoli Federico II}

„Ke kořenům evropské právní kultury. Starověké texty a dokumenty mezi jazykem a právem" (Alle radici della cultura giuridica europea. Testi e documenti antichi tra lingua e diritto / The roots of the European legal culture. Ancient texts and documents between language and law) - takové bylo téma letní školy pořádané v týdnu od 18. do 24. záŕí 2017 Právnickou fakultou neapolské univerzity Federico II ve spolupráci s Mezifakultním centrem „Vincenzo Arangio-Ruiz“, Consorzio Interuniversitario Gérard Boulvert a Centrem římské právní kultury a současných právních systémů Univerzity „Magna Graecia“ v Catanzaru.

Uchazeči o účast, jimiž mohli být jak studenti magisterského, tak doktorského studia, ale také mladí vědci, či př́ípadně další zájemci naprríklad z řad praktikujících právníků, se hlásili elektronicky e-mailem, k němuž přiložili CV a případně další dokumenty, které měli za relevantní pro prokázání zájmu o obor. Vybráno bylo 42 účastníků opět v pestrém složení - z Bulharska, České republiky, Číny, Chile, Itálie, Mexika, Německa, Nizozemska, Řecka, Srbska, Španělska, Švýcarska, Turecka, Ukrajiny a USA. Přednášky byly vedeny v italském nebo anglickém jazyce.

Cílem letní školy bylo přiblížit účastníkům dokumenty různorodých forem, které slouží k poznání římského práva a jeho uplatňování v praxi, a to zvláště s proveniencí z oblasti Kampánie. Velmi vítaným doplňkem teoretických přednášek konaných na univerzitě byly návštěvy významných míst - archeologických lokalit, muzeí a knihoven - uchovávajících svědectví antické doby se zasvěceným komentářem odborníků, které umožnily také prakticky nahlédnout pod pokličku procesu zkoumání starověkých nápisů a dalších památek majících co říci o tehdejším právním uspořádání.

V pondělí 18. zář́ se účastníci sešli k registraci a úvodnímu přivítání organizátory letní školy v budově univerzity na Corso Umberto I, v Aula Pessina. Poté program plynule přešel k první přednášce, v níž Giuseppe Camodeca z Università degli studi di Napoli L'Orientale hovořil o právních dokumentech z Kampánie (z nejznámějších míst lze zmínit Pompeje, Herkulaneum a Pozzuoli), z nichž jsou důležité obzvláště záznamy o běžném životě, at' už z hlediska aktivit obchodních nebo třeba i procesněprávních. Prostřednictvím powerpointové prezentace také seznámil účastníky s podobou nositele takových záznamů - obvykle trrí k sobě svázaných tabulek opatřených pečetěmi. Po obědě se konala přednáška Francescy Reduzzi z Università degli studi di Napoli Federico II o obchodních dokumentech v ř́mské říši, kdy byly demonstrovány konkrétní př́íklady týkající se prodeje otroků.

Hned v úterý se celá skupina vypravila na první z výletů - na Flegrejská pole (Campi Flegrei). V této archeologicky významné oblasti západně od Neapole, známé v současné době i sopečnou aktivitou projevující se kritickým hromaděním sopečných výparů-plynů pod povrchem, jsme alespoň zvenčí viděli třetí největší amfiteátr v Itálii. Zavítali jsme také do obří římské vodní cisterny zvané Piscina Mirabilis. Čekala nás i prohlídka Archeologického muzea Flegrejských polí situovaného na Castello aragonese v části Baia. V téže části se také nachází archeologický komplex, jehož návštěvou jsme tento den zakončili. Velmi zásadní součástí celého dne byl samozřejmě odborný výklad profesora Camodecy. 
Středa 20. záŕí přinesla další rozbory antických textů. Konkrétně byl Wernerem Eckem (Universität zu Köln) analyzován jistý úsek císařské politiky prostřednictvím císařských konstitucí o udílení římského občanství rekonstruovaných díky textům vojenských diplomů - bronzových destiček dokládajících čestné propuštění z armády. Isabella Piro z univerzity Magna Graecia v Catanzaru se zabývala právním jazykem jako nástrojem konceptuální syntézy na př́íkladu pojmů týkajících se manželství. Také Jakub Urbanik (Uniwersytet Warszawski) zůstal u tématu sňatků a rozvodů a na př́padových studiích poukázal na různorodé otázky, které vyvstávají z dochovaných dokumentů, např́klad úpravy vzájemných práv a povinností, řešení situace, kdy manželství uzavírají osoby řídící se různými právními řády v důsledku principu personality práva, atd. Odpoledne si účastníci letní školy mohli prohlédnout bohatou romanistickou knihovnu univerzity.

Ve čtvrtek 21. září přednesl Jakub Urbanik referát José Luise Alonsa z Universität Zürich, který se osobně nemohl dostavit, a to na téma Constitutio Antoniniana a právní praxe po přijetí této císařské konstituce na příkladu několika dochovaných textů na papyrech. Pak pokračovala Fara Nasti (Università degli Studi di Cassino e del Lazio Meridionale), která se věnovala epigrafickým a papyrologickým památkám z oblasti dědického práva. Součástí této přednášky byl také velmi zajímavý rozbor dvou testamentů ze 2 . stol. n. 1 . Annamaria Salomone (Università degli studi di Napoli Federico II) se věnovala právním institutům darování a směny a právní terminologii v jednotlivých římskoprávních pramenech práva, která se $\mathrm{k}$ nim váže. $\mathrm{K}$ testamentům se ve své přednášce vrátila Carla Masi Doria (Università degli studi di Napoli Federico II), konkrétně k nově objevené závěti římského občana ze 4. století ze severní Afriky, jejíž znění je dochováno téměř celé a bude vydáno v časopise Index.

Poslední přednáškový den zahájila Giovanna Daniela Merola (Università degli studi di Napoli Federico II) porovnáním teorie a praxe výkonu spravedlnosti v provinciích, přičemž ohledně procesní praxe poskytují svědectví právě papyry pocházející z oblasti středního Eufratu. Maria Chiara Scappaticcio (Università degli studi di Napoli Federico II) se zabývala výukou latiny ve starověku, přičemž v této souvislosti lze zmínit dílo Grammatici Latini, soubor př́ruček latinské gramatiky vytvořených během 2.-7. stol. n. 1., jehož některé pasáže byly v rámci přenášeného tématu také využity. Rosanna Sornicola (Università degli studi di Napoli Federico II) prezentovala dílčí výsledky běžícího projektu týkajícího se jazykového výzkumu byzantských a langobardských listinných dokumentů z jižní Itálie z 9. a 10. století. Nakonec vystoupil Cosimo Cascione (Università degli studi di Napoli Federico II) a strhl účastníky svým nenapodobitelným projevem, v němž se zabýval otázkou mnohojazyčnosti a multikulturalismu v římském světě a především v právu, vztahem Římanů s ostatními národy, především s Řeky, a přebíráním řeckých kulturních vzorců a vymezování se vůči nim, vše na podkladě právních i neprávních textů i epigrafických památek.

Večer se pak konalo slavnostní zakončení s předáváním účastnických certifikátů. Tím ale aktivity letní školy neskončily, nebot' sobota 23. záŕí byla zasvěcena prohlídce archeologického areálu v Pompejích a nedělní dopoledne návštěvě Národního archeologického muzea v Neapoli, především jako epigrafické kolekci, k níž dostali účastníci obsáhlý výklad. Komu se ještě nechtělo se loučit, mohl následně ještě strávit v družném hovoru odpoledne s profesory neapolské univerzity, Carlou Masi Doria a Cosimem Casione. 
Týdenní intenzivní kurz propojil právní a jazykovou problematiku, poukázal na význam dokumentů z běžného života, dokládajících ono „law in action“ oproti teoretickému „law in books“, a umožnil nahlédnout z jiné perspektivy i na místa, kam se mnozí účastníci již dříve dostali jako „pouzi“ turisté. Letní škola spojila skupinu nadšených lidí z různých vědních oborů, kteří mezi sebou navázali nejen profesní kontakty, ale i kamarádství a sdíleli svůj zájem o svět starověkého Ríma.

doi: 10.14712/2464689X.2018.62

Kamila Stloukalová 